\title{
The Materials for a Study of Greek Law
}

W

HEN the humanists of the Renaissance, fired with new enthusiasms, addressed themselves to the task of collecting and interpreting the remains of ancient Greek literature, they found that much of the best had survived the appalling destruction and more appalling neglect of the Middle Ages. There were, it is true, irreparable losses, gaps they could never hope to see filled, but most departments of human thought were represented by the work of some great master. By the time the task of recovery and restoration was well under way, it was possible to study and evaluate from worthy specimens the achievements of ancient Hellas in epic and dramatic poetry, in history, in political and forensic eloquence, in philosophy, in mathematics and the natural sciences, and to some extent in the study of politics. ${ }^{2}$ Even the devotee of art and architecture found first and last a surprising amount of material in scattered relics which had survived here and there to keep alive the ancient Greek conception of the beautiful. But the student of law and of legal history was not so fortunate; where others found both the means and the incentive to their researches, he was confronted by a void; in all extant writings of the Hellenes there was no authoritative treatise upon law and no systematic collection of Greek laws, nothing in any way comparable to the great Corpus Juris or to any of its parts. ${ }^{3}$

With the circumstances that brought about this situation and its inevitable consequences we are not now immediately concerned. It will suffice to say that the determining factor in the complete disappearance of the ancient Greek legal texts was probably the pronounced vocational trend of legal studies throughout the Roman world. The texts of classic Greek authors most likely to be pre-

1 Since this paper is intended for students of general jurisprudence rather than for specialists in Greek law, references are mainly to works that will be easily accessible; these will generally yield abundant suggestions for further reading. Information on the lives and writings of the various authors discussed will be found in any of the better histories of Greek literature. For a discussion of the sources from a somewhat different point of view and a more detailed description of the works of ancient authors, cf. Barrilleau, Des sources du droit grecque (Paris, 1883).

2 An extremely interesting account of the recovery of these ancient texts is found in Sandys, History of Classical Scholarship, II (Cambridge, 1908), especially $25 \mathrm{ff}$.

${ }^{3}$ Cf. 11 California Law Review, 301. 
served through ancient times, apart from a few happy exceptions, for which we should be duly thankful, were those which were studied in the schools. The manuscripts from which the pupils studied or the professors lectured, by reason of their relative abundance, stood a good chance of being copied and finding their way, first into the collections of the monasteries, and later, in sadly dwindled numbers, into the eager hands of the early humanists. ${ }^{4}$ The student of literature or philosophy, the budding poet or historian, the youth ambitious to become an orator, could not afford to neglect the great masterpieces of the past. But the liberal and scientific study of law, as of nature, seems to have ended with Theophrastus. $^{5}$ The student in the Roman law school had seldom the time or the inclination to delve into the legal systems of other peoples and other times; his eyes were fixed rather upon a successful and profitable practice than upon the fundamental principles of jurisprudence; to win cases was his ambition, and to learn by rote the legal rules of his own time and place seemed to him the shortest road to success-none too short at that, when we think of the complex and ponderous accumulations that made up the law of the empire before Justinian. The obsolete statutes of the Greek citystate crumbled away unheeded, and the collections and treatises of an earlier age were allowed to disappear; the only Greek law that found its way into the schools was that which had been incorporated into the law of the empire or still prevailed in some of the eastern provinces, with here and there a brief quotation embedded in the commentaries of the great jurisconsults. ${ }^{6}$

The task of recovery and reconstruction has been both slow and arduous. The collections we now possess have had to be built up, line by line and page by page, with minute and painstaking research, from scattered sources, from inscriptions that are often mere fragments, from bits of papyrus found in the rubbish heaps of forgotten cities, from ex parte arguments of ancient litigants and counsel,

4 Manuscripts were reproduced for use in the schools not only in great numbers but in the form of parchment codices, which were more durable than papyrus rolls; cf. Birt, Abriss des antiken Buchwesen (Murich, 1913, Iwan Mueller Handbuch I, iii), 353.

5 For the achievements of Theophrastus in the natural sciences, cf. The Legacy of Greece (Oxford, 1922), 176 ff., especially 183; on his juristic works, cf. infra, p. 475.

6 On the survival of Greek law in the eastern provinces the famous study of Mitteis, Reichsrecht und Volksrecht (Leipzig, 1891) may best be consulted. For typical examples of Greek quotations from the jurisconsults, of Barrilleau, op. cit., 3. 
from chance allusions in the writings of the Greek historians and philosophers and even the poets. No one branch of philological science by itself has been equal to the task; the combined labors of the archæologist, the epigraphist, the palæographer and papyrologist, the textual critic, the specialist in the Greek dialects, even the numismatist, have been needed to prepare the materials for the student of Greek legal antiquities, whose delicate but fascinating task it is to select and compare them and finally to combine his approved results, so far as may be possible, into an orderly and systematic whole. It is small wonder that the student of general jurisprudence and of legal history has so frequently yielded to the temptation to leave the study of Greek law to the philologist-and then perhaps to dismiss that worthy's researches with the contemptuous epithet "antiquarian." It has proved vastly easier and more comfortable to settle down before the fire with a good modern text of the Corpus Juris and soothe the occasional twinges of intellectual curiosity that even the most confirmed dogmatist must occasionally feel with the false old truism that the Greeks were incapable of developing or applying a scientific jurisprudence.

Thanks to the labors so summarily dismissed, our knowledge of Greek, and especially of the Attic, law is now very considerable, and is increasing so rapidly, as a result of constant discoveries of new material, that we may well think of the science as in its infancy. Yet, despite the progress that has been made, the student whose ambition aims at something more than mere reporting and compilation, who wishes to strike out new paths and discover new truth, still finds it necessary, like his predecessors, to delve amid multifarious and scattered sources. To classify these sources in the order of their importance would be an extremely difficult task. A primary source of unimpeachable authority, for example the official transcript of an ancient law on stone, may have come down to us as a mutilated fragment, containing only a few lines, or even words. On the other hand, the work of some obscure lexicographer, written centuries later than the times of which it treats, and abounding in ridiculous errors, may assume great importance merely from its lengthy and exhaustive character. I shall, however, undertake to discuss the various sources with some regard to the general order of their importance, giving examples that are of especial interest because they illustrate the problems of the investigator, his minute and painstaking labors, his reverses and his triumphs. It is scarcely 
necessary to say that my discussion does not profess to make any addition to the knowledge of the worker in this field, or to suggest improvement in critical methods; it is intended for the student of general jurisprudence who, although he has not had the opportunity of studying Greek law at first hand, may nevertheless desire to know something of the materials upon which our present knowledge is founded and the ways in which they have been studied.

\section{INSCRIPTIONS}

Written law first made its appearance among the Hellenes in the seventh century before Christ, and it was not long before every city-state of any importance had erected in its public places tablets of wood, stone, or bronze, inscribed with the texts of its law. ${ }^{7}$ Since in some states, notably in Athens, the arrangement and subdivisions of the law corresponded to the various jurisdictions, it is not unlikely that the rules of law enforced by each court were to be found near the chambers of the examining magistrates. ${ }^{8}$ Not infrequently the surface of a building or a wall bordering upon a public square or walk bore the inscription, ${ }^{9}$ a striking testimony to the comparative conservatism of the ancient legislator. Since all citizens enjoyed free access to these authentic texts, which could be consulted or copied at will by litigants, serious garbling or misquo-

tation of laws before the courts must have been a somewhat dangerous proceeding.

It is extremely fortunate that the Greek cities were generally well supplied with marble, or other stone suitable for inscription, and used this material more frequently than bronze. Very few tablets of bronze or other metals escaped the melting pot, when once their legends had become obsolete. On the other hand, slabs of marble, although occasionally they found their way into the lime kiln, were less likely to be totally destroyed; they might be thrown down, or broken, or buried, or even built into the masonry of new structures, but the writing on them was likely to be preserved in a more or less legible condition. In a few cases the full text of a

7 Aristotle tells us (Cons. Ath. vii. 1) that Solon's laws were inscribed on kyrbeis and placed in the King's Portico (cf. And. i. 85).

8 On the subdivisions of the Attic corpus juris, cf. Dem. xxiv. 20; Lipsius, Das attische Recht und Rechtsverfahren (Leipzig, 1905-1915), 56, n. 10. However it may be that all or most of the laws were published in the King's Portico (cf. And. i. 84-85).

9E. g., the great inscription from Gortyna (infra, p. $467 \mathrm{f}$ ). 
lengthy inscription has been found in a state of almost complete preservation; in others little is left, but that little is of inestimable value to the student.

As a result of the systematic exploration of ancient sites, we now have many thousands of inscriptional texts and hundreds are being published each year. A fair proportion are of a legal or quasi-legal character $;^{10}$ these represent all the more important centers of Greek life, and range in date from the sixth century before Christ far down into Roman and Christian times. They illustrate almost every process or transaction that can be imagined in the realm of public or private law; among them are statutes; resolutions and decrees of various legislative bodies; rescripts of kings and emperors; fiscal and judicial records (e. g. judgments, lists of proscribed persons, inventories of state properties, treasury accounts, etc.); ordinances and rules of associations and corporations, both public and private; records of contracts, of the manumission of slaves, of sales, leases, and mortgages, and the terms of bequests and foundations. International law and custom are abundantly illustrated by treaties, awards entered in the arbitration of international disputes, and other records. Such contemporary authentic documents, among them many official texts of statutes, are of course sources of the very first order of importance. ${ }^{11}$

The longest and perhaps the most important of these texts is the famous inscription from Gortyna in Crete. ${ }^{12}$ This was discovered in 1884 on an ancient wall, some twenty-seven feet long and five feet high, which had apparently formed part of a public building. ${ }^{13}$ Before the writing could be transcribed in its entirety, it was necessary to excavate the wall at one end and to expose it at the other by diversion of a mill stream. When this had been done, however, almost the entire text was found in an excellent state of preservation, comprising more than six hundred lines, arranged

${ }^{10} \mathrm{~A}$ few of the most important and interesting have been published, with excellent translations and commentary, by Dareste-Haussoullier-Reinach, Recueil des inscriptions juridiques grecques (Paris, 1891-1904). A good idea of the information on legal subjects contained in the inscriptions can be got from Michel, Recueil d'inscriptions grecques (Brussels, 1900); of the 1426 titles, by far the greater number have legal implications.

11 Hicks and Hill, Greek Historical Inscriptions (Oxford, 1901), p. xiii; Michel, op. cit., p. ix; Barrilleau, op. cit., $29 \mathrm{f}$.

12 Ins. jur. grecques XVII; English translations by Merriam, "Law Code of the Kretan Gortyna", Am. Jour. Arch. I (1885), $324 \mathrm{ff}$., II (1886), $24 \mathrm{ff}$., and by Roby, "The Twelve Tables of Gortyn", 2 Iraw Quarterly Review (1886), 135 ff.

${ }_{13}$ The inscription was discovered on part of a circular wall belonging 
in twelve columns. The inscription is evidently a collection of novellae, amendments and additions to the code, enacted on some occasion when the laws were subjected to thoroughgoing revision. ${ }^{14}$ Among the subjects treated at considerable length are disputes over ownership of slaves; rape and adultery; property rights of widows and divorcees; succession to property; the rights and obligations of "heiresses"; ;5 adoption. The inestimable value of this document and its far-reaching implications can be understood only by one who has reviewed the voluminous literature of comment and interpretation to which it has given rise.

The preservation of this long inscription virtually intact, is, however, an exceptional bit of good fortune. The fragmentary character of most inscriptional sources and the multifarious difficulties involved in their restoration and interpretation may be illustrated from another of our earliest legal monuments, the tablet on which the ancient Attic law on homicide traditionally attributed to Dracon was engraved in $409 / 8$ B. C. ${ }^{16}$ The resolution of the council and assembly ordering the republication of the law is in a fair state of preservation; when we come to the actual text of the law, however, we find only fragments of some forty lines, in no case showing more than half of a line, and often merely a few letters. The restoration of about thirty lines has enlisted the efforts of many scholars during a period of eighty years. The text as it stands at present was constituted after a close study of all the many quotations and citations of the laws on homicide in the pages of the Attic orators $;^{17}$ the result has been satisfactory in more ways than one, since it has shown that quotations from laws found in the orators may in general be regarded as accurate. ${ }^{18}$

to a theatre of the first century A. D., but the blocks had apparently been taken from a more ancient building, probably the town hall or dikasterion of the classical city (Hicks and Hill, op. cit., 53). p. iv.

14 Kohler and Ziebarth, Das Stadtrecht von Gortyn (Göttingen, 1912),

15 The word "heiress" is here used in the special sense of a woman who is left, at her father's death, without brothers.

16 Ins. jur. grecques XXI=Hicks and Hill LXXVIII.

17 This will appear from a study of the textual notes in Ins. jur. grecques II, 5 ff.; cf. also Koehler, "Attische Inschriften" Hermes II (1867), 27 ff.

18 Even the documents inserted in the text, which once were indiscriminately denounced as forgeries, have been found in many cases to be genuine (cf. Drerup, "Ueber die bei den attikern Rednern eingelegten Urkunden." Jahrb. f. klass. phil. Supplbd. XXIV (1898), 221 ff.), and are not now generally rejected without definite reason (cf. Barrilleau, op. cit., 8). 


\section{Papyri}

The achievements of the last forty or fifty years in the recovery of inscriptions are equalled or exceeded by the discoveries of papyrus manuscripts. ${ }^{19}$ These have been collected and published literally by thousands, and range all the way from whole texts of literary works down to tiny scraps of private memoranda. They come almost without exception from Egypt, where the dryness of the atmosphere has had the happy result of preserving them for two thousand years or more, not only in the carefully sealed tombs but even in the heaps of rubbish and sand that mark the former sites of vanished cities. What sets them apart from other manuscripts and gives them a peculiar importance to the student of Greek law is the circumstance that a very large proportion of the single sheets and fragments are instruments of a legal or quasi-legal nature. ${ }^{20}$ Like the Babylonians, the people of Hellenistic Egypt seem never to have passed by an opportunity to execute a written instrument, and every transaction, from the payment of a trifling sum to a contract of great importance, was set down in writing. From these documents, which are fairly plentiful for the last two centuries of the Ptolemaic period as well as for Roman and Byzantine times, scholars have been able to reconstitute with some certainty the Greek law of the Hellenistic age as it existed in Egypt, and to trace the history of its development in Roman times. As might be expected, the materials are more abundant on the side of private law and enable us to form a very good idea of the legal rules which had to do with property and succession, contracts, sales, mortgages, leases, and banking. ${ }^{21}$ To be sure, there are still many points on which we have little or no information, but there is every reason to hope that further discoveries of material will make it possible eventually to fill these gaps.

In addition to the multifarious collections of documents connected with particular transactions, we have a number of manuscripts which give us the actual texts of the law, chief among them the cele-

${ }^{19} \mathrm{~A}$ good brief account of various discoveries and a few notable manuscripts will be found in the Encyclopaedia Britannica XX, 557 ff. (s. v. Palæography).

${ }^{20}$ With these must be considered the ostraka, or broken pieces of pottery, which were much used for short documents, since they cost only the trouble of picking them up; like the papyri; these have been recovered and published in great numbers. Wilcken, Griechische Ostraka (Leipzig and Berlin, 1899).

${ }_{2 i}$ The student may well begin with Mitteis-Wilcken, Grundzïge und 
brated papyrus containing the Revenue Laws of Ptolemy Philadelphus. ${ }^{22}$ Perhaps the most interesting of all to the student of Greek law is a collection of excerpts from the Alexandrian code of the second century before Christ; it was written out apparently for use by a lawyer in the preparation of his cases, and contains among other matters lengthy citations from the law governing the prosecution of perjury. ${ }^{23}$

The value to the student of such authentic contemporary sources, comparable to the inscriptions which present the original official texts of statutes, needs no further comment to be readily appreciated. The discovery of these sources has now made it possible to treat with scientific precision a body of law which was as recently as fifty years ago virtually unknown; it has brought us a great deal nearer to the time when we shall be able to envisage the development of legal institutions as a continuous evolutionary process extending back into remote antiquity.

\section{The Attic Orators}

Despite the progress that is being made in the recovery and interpretation of inscriptions and papyri, the student who is interested primarily in the Attic law of the fifth and fourth centuries must still rely principally upon the forensic speeches which have come down to us under the names of the ten great Attic orators. ${ }^{24}$ In some ways these are less satisfactory as sources than our epigraphical materials. Even without taking account of the minor inaccuracies that have crept into our texts during a long course of manuscript tradition, no particular passage in the orators can be regarded as of equal authority with an original epigraphical text. The speeches are admittedly ex parte statements of litigants or counsel, made with intent to influence a court in its decision, and

Chrestomathie der Papyruskunde (Leipzig and Berlin, 1912), especially Vol. II, where he will find abundant references to the source collections and special works.

${ }^{22}$ Grenfell and Mahaffy, The Revenue Laws of Ptolemy Philadelphus (Oxford, 1896).

${ }^{23}$ Dikaiomata. Auszïge aus Alexandrinischen Gesetzen und Verordnungen (Berlin, 1913).

24 For an excellent account of the orators, with brief summaries of the speeches, cf. Jebb, The Attic Orators from Antiphon to Isaeus (London, 1893). 
too often filled with sentiment and sophistry.25 Consequently, if they are to be utilized as sources, the investigator's task is one of exceeding delicacy and calls for the constant exercise of keenly critical judgment. ${ }^{26}$ But if this is kept in mind and the speeches are used with proper caution, their importance can scarcely be overstated, since they comprise first-hand contemporary presentations of the law and the facts in a great number of cases. Merely on the score of the amount of information they contain and their comparatively perfect state of preservation, as contrasted with the fragmentary character of most inscriptions and papyri, they unquestionably outrank in the aggregate any and all other sources for the time from which they come.

As the papyri illustrate the Greek law of the Hellenistic age, so the orators present to us the Attic law in its maturity and highest perfection. From Antiphon to the contemporaries of Demosthenes, they cover the period of nearly one hundred years preceding the overthrow of the independent city-states by Macedon. They constitute a collection of more than one hundred and fifty speeches, many of them arguments actually delivered in court by litigants or counsel, representing criminal and civil proceedings of many sorts. Homicide, assaults of various kinds, adultery, perjury, trespass, treason, usurpation of civic rights, blackmail, bribery, malfeasance in office, and military desertion are some of the offenses to which we are introduced. Among the purely civil actions represented are suits to establish title to estates, to recover loans, suits for damage arising from various causes, suits of wards against guardians, actions arising upon breach of contract, and many others. Furthermore, the orators contain a wealth of information upon many subjects far removed from the law, and we find in their pages a fascinating series of pictures from the daily life of the average Athenian. ${ }^{27}$

The modern reader of the orators will at once note that the speeches attributed to Antiphon are exclusively arguments in homicide cases, while those which represent the work of Isaeus were, with a single exception, delivered in trials of inheritance cases. On the other hand, the extant speeches of the other orators are not restricted

25 For a vigorous statement of this viewpoint, cf. Wyse, The Speeches of Isaeus (Cambridge, 1904), 177 f., 235 f., 299 f., 382, and elsewhere through out the commentary.

26 I have discussed briefly some of the problems involved in the use of the orators as sources in 24 Coltumbia Law Review, $160 \mathrm{ff}$.

${ }^{27}$ Barrilleau, op. cit., 2. 
to any particular type of proceeding, and the work of the two great masters, Demosthenes and Lysias, ranges over virtually the whole field of law. This rather curious circumstance apparently results from the fact that Antiphon and Isaeus had each a specialty in which he excelled, and the selections compiled for use as textbooks in the Hellenistic and Roman schools of rhetoric were intended to illustrate their work in these particular fields. ${ }^{28}$ Demosthenes, however, with his transcendent genius, was probably the most eagerly sought after of all the "speech-writers," as long as he followed the profession, and very naturally was retained in all sorts of cases. ${ }^{29}$ In somewhat the same way the peculiar talents of Lysias, who was famous for the skill with which he put his client's personality into the speech which he composed for him, may have led to his undertaking all kinds of cases; his specialty was psychology, rather than any particular department of law.

\section{Treatises on LaW and Government}

To arrange in the order of their importance the various treatises on government and law that have come down in a more or less complete form is a matter of great delicacy. No one formula of criticism will serve for two different works, or even for different parts of the same work. When Aristotle for example tells us something about the Athenian courts of his own day we accept his statement with little hesitation; but when a few pages on he describes the practices of an earlier period or of a remote country we cannot be so certain. There are many factors that must be considered in deciding what credence we are justified in giving to any particular statement of fact; we must ask what were the author's means of acquiring information, his powers of observation and analysis, his motives and possible bias, his regard for accuracy and truth, and other like questions. The formula is a complex one and constantly changing.

Among the works now extant, students of Attic law will probably agree in giving first place to the famous Aristotelian Constitution of

${ }^{28}$ Croiset, Histoire de la littèrature grecque IV (Paris, 1899), 72.

${ }^{29}$ It must be remembered that arguments by professional counsel were forbidden by the Attic law; to evade this prohibition, litigants employed "speech-writers" to study their cases and compose for them arguments which they themselves delivered before the court. 
Athens. ${ }^{80}$ This treatise, which was greatly esteemed and widely quoted among the ancients, disappeared in the seventh century of the Christian era apparently, and until the closing years of the nineteenth century was known to us only through the allusions and brief quotations of other writers, chiefly the lexicographers, and some short fragments of papyrus. In 1889, however, a text of the lost work was discovered in Egypt, in the form of an excellent papyrus manuscript of the first or second century A. D.; portions of the work at the beginning and at the end were lacking, but by far the greater part was in a very fair condition. The editio princeps was published in 1891 by the British Museum, which had acquired the manuscript, and the treatise immediately became the focus of scholarly activity; in the thirty odd years since its discovery it has been repeatedly edited, translated into many languages, and made the text of countless learned dissertations; furthermore, its appearance made it necessary to revise practically every work that had to do with the legal and constitutional antiquities of Greece.

The treatise consists of two parts, a constitutional history of Athens from the earliest times, and a systematic exposition of the constitution as it existed in the time of Aristotle. Although both parts are of the very greatest importance, they are of unequal value. The historical portion is in the main a compilation of materials drawn from the works of other writers; apparently Aristotle intended it to be a brief, popular account and was at no particular pains to adopt a severely critical attitude toward his sources; there are numerous indications that at some points he followed the pseudohistorical works of party pamphleteers, without making proper allowance for their bias, and at others relied on secondary sources when he might well have consulted original official records. However, despite the constant need for caution in following this portion of the work, it preserves a great deal of important information on periods froin which no other records have come down to us. The second part, a systematic and detailed account of the legislative, executive, and judicial machinery of Athens, must be regarded as a source of the very first order, a contemporary document whose author was a trained scientific observer, one of the world's greatest philosophers and political thinkers.

${ }^{30}$ An excellent edition by Sandys, with introduction, exhaustive bibliography, and notes (2d ed., Cambridge, 1912); English translation (London, 1920) by Kenyon, editor of the editio princeps; for a good brief account, see Encyclopædia Britannica VII, $16 \mathrm{ff}$. (s. v. Constitution of Athens.) 
Aristotle's treatise on government, the Politics, is a work of more philosophical character, and, in the general field of political science, of far greater importance than the Constitution of Athens, but of less immediate value for the study of legal history. It contains a vast fund of information on constitutional law, applying not merely to Athens but to many other states, and develops in a scientific and logical manner many fundamental principles of government. But aside from constitutional law, the information it yields is less abundant and specific than might be looked for in a work of its length. No student of the law can afford to pass by the Ethics, or the Rhetoric.

The dialogues of Plato of course take rank among our most important and valuable sources. Although the student is apt to think first of the Laws and the Republic, he cannot afford to neglect the minor dialogues. At any moment he may find legal practices and concepts brought into the discussion, and it would be difficult to imagine a better introduction to the study of Attic law than is to be found in the first four dialogues, which depict the trial and death of Socrates. Of the two great dialogues, the Laws naturally contains much more information on substantive law than the Republic, being concerned to a greater degree with the application of political principles than with their theoretical development and philosophical justification. Both dialogues call for critical discrimination if they are to be used as sources. The reader of the Republic must not forget that the primary purpose is not so much to outline a Utopian state as to develop certain fundamental ethical conceptions. In the Laws it is often difficult to determine when Plato is copying existing legal rules and practices and when he is suggesting innovations. Certain of the spurious dialogues are of very considerable importance even though they cannot be regarded as the work of Plato. ${ }^{31}$

There are a number of brief treatises which may be mentioned at this point, especially Xenophon's account of the Spartan constitution and his pamphlet on the Revenues of Athens, as well as the bitterly brilliant attack upon the Athenian democracy formerly attributed to Xenophon but now regarded as the work of an oligarchic doctrinaire of the fifth century. ${ }^{32}$

31E. g., the Minos.

32 Cf. Busolt, Griechische Geschichte III (Gotha, 1904), 609 ff. 
One need only glance at the few fragments of the famous treatise on law by Theophrastus to realize how tremendously important the work must have been and how irreparable is its loss. ${ }^{33}$

\section{The Lexicographers and Scholiasts}

As a result of the changes to which Greek, in common with all living languages, was inevitably subjected, the Alexandrian and Roman students of the classical masterpieces found as time went on an increasing number of words and phrases they could not readily understand. To meet this difficulty, the learned professors who lectured in the ancient schools began to note upon the margins of their manuscripts the meanings of unfamiliar words and expressions, brief comments on names of persons or of places, explanations of historical or literary allusions, textual and grammatical matters, and similar memoranda. Thus originated the earliest commentaries, called "scholia"." The advantages of collecting such notes and arranging them in alphabetical order were soon perceived, and it was not long before the apparatus of ancient scholarship was enriched by the works of various "lexicographers", who compiled "lexica", or dictionaries, containing much information of a linguistic or antiquarian nature. ${ }^{35}$ Naturally the technical terms connected with legal and political phenomena which had gradually disappeared to make way for newer institutions were among the most difficult to understand. For this reason the ancient "scholia" and "lexica", especially those relating particularly to the works of the Attic orators, abound in bits of miscellaneous information-and misinformation-on ancient law. The materials thus preserved are of great importance, partly by reason of their abundance, and partly because the authors had access to many ancient works which now are lost. On the other hand, the scholiasts and lexicographers were men of very unequal ability and knowledge; some of them were evidently both stupid and ignorant, and many preferred the wildest guess to a confession of ignorance. Consequently, although the student must rely upon their statements when he has no good reason for calling them in question, he must discard them without hesitation when they conflict with worthier sources.

33 11 California Law Review, 300, n. 17.

34 Sandys, History of Classical Scholarship I, index, s. v. "scholia." 35 Ibid., 322 ff., 378, $399 \mathrm{f}$. 


\section{Historians}

It need scarcely be said that the historians have preserved for us a vast amount of information, much of it extremely valuable. The extraction of this material, however, often is no easy task, and calls for critical acumen and scientific training of the highest order. In general the problems of criticism are similar to those encountered in the study of treatises on law and government, ${ }^{36}$ though the historian is perhaps more likely to be influenced by his personal viewpoint in recording matters of which he has immediate knowledge.

The works of Herodotus acquire an especial value from the author's wide experience, catholic interests, and restless curiosity; those of Thucydides from his profoundly philosophic attitude and exceptionally critical turn of mind; those of Xenophon from his practical wisdom, his unusual opportunities for observation, and his active interest in political problems. Of the last-named writer it may be said that we are in less danger of being misled by his biased point of view than of underestimating his keenness of observation. and his good sense. Later historians are in the nature of things entitled to less credence than their great predecessors, but their works cover many periods which would otherwise be quite unknown to us. Furthermore they frequently quote explicitly from earlier and more trustworthy authors; for example, we cannot regard Plutarch as in any sense a critical historian, but he has the admirable habit of frequently mentioning his sources.

Any account of the historians, however sketchy it may be, must mention the important fragment of a fourth-century historian, probably Theopompus, discovered a few years ago at Oxyrhynchus in Egypt. From it we have gained a brief but particular description of the Boeotian federal government, and have learned that the ancients were familiar with the principle of representation. ${ }^{3 \tau}$

\section{The Poets. Aristophanes, 'Homer, the Dramatists}

Among the poets of the classic period, the incomparable Aristophanes stands in a class by himself as a source of information on the law and judicial machinery of the fifth and early fourth

36 Supra. p. 472.

37 Grenfell and Hunt, Hellenica Oxyrhynchia (Oxford, 1909) ; cf. Bonner, "The Boeotian Federal Constitution", Class. Phil. V (1910), 405 ff. 
centuries. As I have elsewhere observed, ${ }^{38}$ the business of government and law in his day came closer home to the average individual than in any other age, and his earlier comedies have to do almost exclusively with political and legal problems. They are a veritable mine of information, but the student must delve with extremely delicate strokes if he is not to bring out more dross than precious metal; he must never forget that the pictures so skillfully painted are caricature and extravaganza, beneath which the true outlines are concealed as on a palimpsest. While many of the plays abound in information regarding Attic law, first place must of course be given to the Wasps.

Tragedy naturally has less to offer on our subject, but cannot be passed over. In Aeschylus are reflected fifth century notions of law and justice, with here and there an attempt to reconstruct the thought of earlier times; Sophocles is often preoccupied with the fundamental principles of right and wrong and with human attempts to apply them through the law; Euripides constantly glances at the legal activities of his day, especially in the clever debates for which he found a pattern in the arguments of litigants before the courts.

As we work backward froin the fifth century, we meet with echoes of earlier notions of justice and of law in the fragments of the lyric poets, especially Solon, and finally, in the Homeric poems, we come very near to the beginnings of Greek law. As I have already had occasion to point out, we are singularly fortunate in having so early and so extensive a body of material as the Homeric epic from which to study the tribal institutions of the Greeks. ${ }^{39}$ The value of this source is enhanced by the very fact that the concepts we are most interested in studying "were not yet the subjects of conscious observation"; consequently the poems in a way portray these concepts with greater fidelity than do later writings whose authors were unconsciously influenced by their preconceptions. ${ }^{40}$

In this discussion it has not been possible to do more than touch upon what is most important, or most striking, or lends itself most readily to effective illustration, for an adequate account might well deserve a volume by itself. Whatever value the paper may possess will lie not so much in the information it contains, most of which

3811 California Law Review, 305, 311.

39 Ibid., $305 \mathrm{f}$.

40 Maine, Ancient Law (4 Am. ed.), 2 f. 
is somewhat familiar and elementary, as in the invitation it extends to students of legal history to consult these sources for themselves, to learn something of Greek law at first hand, and perhaps ultimately to undertake investigations in a field of exceeding interest and increasing importance.

University of California, Berkeley, California.

George Miller Calhoun.

Professor Calhoun's article in this number on so remote a matter as Greek law can be connected with a most recent case, on which a note appears on page 532 of this ReviEw.

In the last volume (XVI) of the Oxyrhynchus-Papyri, 1924, No. 1901, there is the will of one Flavius Pousi, made in the early part of the sixth century, and therefore almost exactly contemporary with the Corpus Iuris Civilis of Justinian. It is cited here in extenso, primarily because it contains a non-contesting clause involving a forfeiture in case it is violated, precisely the question which, as the case just cited proves, is still agitating the courts.

Wills with provisions somewhat like this have been found before. There is, for example, the will of $480 \mathrm{~A}$. D. found in Antinoë, edited by Seymour de Ricci in Stud. Pal. i, 6, who quotes ther will of St. Gregory of Nazianzus about one hundred years earlier. There is further the will published in the Greek Papyri of the British Museum, Vol. I, p. 231. (Compare also Wien. Stud., 9, 235.) All these wills contain in Greek translation the phrase, dolus malus abesto, or its equivalent, and the Antinoe will contains further the provision: "All others are disinherited, and no one is permitted to contradict this my testament." There is, however, no forfeiture clause nor a gift over:

Earlier Greek wills, such as those discussed in Mitteis-Wilcken, and the will of Hermogenes of 276 A. D. (Pap. Ox. 6,907) do not contain either the dolus malus phrase or the provision against contest. These, therefore, may seem to be a late development, and introduced into the testaments of the Mediterranean world by the Roman law.

\section{Will of Flavius Pousi (Sixth Century A. D.)}

"I wish and direct that Cyria, the wife who has been joined to me, shall inherit her clothing and ornaments found in my house, 
together with the half-share of the remaining half-share of the said house which was sold to me by Epiphanius brother of ... and all the furniture in my house from the chief pieces down to the smallest item. I wish and direct that mistress Manna should have the remaining half-share of the half-share of my said house which was sold by the said person, that is to say, the quarter-share of the whole house, and the small plate and my three spoons and my two caskets, the silver going to her lady mother Taro, and I also wish the said mistress Manna to have the third part of all my clothes, both winter and summer, and the other two-thirds of the said clothes I wish to be given to Sambas and Julianus, couriers, sons of ... because of their devotion to me. I wish and direct that the deeds of gift which I formerly made to my late daughter and Cyria, the wife aforesaid who has been joined to me, should be invalid everywhere where they are produced. I wish and direct that Cyria, the wife who has been joined to me, shall have no power to set aside this my will, and if she shall proceed against it, I wish and direct that she shall take nothing of my property except her own clothing and six solidi of gold ...; and I disinherit all my kindred of either sex. I wish the laying out and burial of my body and my holy offices and services for the repose of my soul to be conducted through the good faith of my heirs aforesaid, and I wish and direct that the halfshare of my allowance in kind be given towards the services and offices, and the other half-share of my said allowance to be given to the aforesaid Cyria. It shall be unlawful for any one to transgress my will or to oppose any of my dispositions, and may guile and malice depart and be absent from this my will, which holds good having been made in the consulship aforesaid, and I have requested the following trusty witnesses to insert their testimony and seal after my signature for the security and support of my associates. (Sigued) I, Flavius Pousi, of the school of couriers of the praeses of Arcadia's staff, son of Paul of blessed memory, the abovewritten, have made the will being sane and in my right mind and walking the earth, and have appointed as heirs the church of St. George called Apa Symeonius' to the half-share of my said entire dwelling, and Cyria, the wife who has been joined to me, to the quarter-share of my said entire house and to the articles of female clothing found in my house and the ornaments and all the furniture in my dwelling from the chief pieces down to the smallest item, and the said mistress Manna to the other quarter-share of my whole dwelling and to the 
small plate that has been used and the three spoons and the two caskets and to the third-share of my clothes, both winter and summer, and the other two-thirds of my said clothes I leave to the aforesaid Sambas and Julianus, couriers, sons of Herais mother of .... I disinherit all my kindred of either sex, and I agree to all that is abovewritten and have signed with my own hand." Attestations of six witnesses.

$-M . R$. 